\title{
Otra perspectiva sobre el deterioro del hormigón de cemento aluminoso
}

\author{
Another look at the deterioration of calcium \\ aluminate cement concrete
}

\begin{abstract}
RESUMEN
La degradación potencial de estructuras de hormigón elaboradas con cemento aluminoso (CA) es bien conocida. Este deterioro está causado por la recristalización (conversión) de las fases del aluminato cálcico que son termodinámicamente metastables, en fases estables. En esta recristalización influye la temperatura y la humedad. Tanto la degradación del propio hormigón, como su pérdida de resistencias están relacionadas estrechamente con la estructura porosa de la pasta del cemento hidratado, siendo parámetros críticos el volumen total de los poros inferiores a 15-20 nm y el tamaño medio de los radios de los microporos. Esto constituye un nuevo procedimiento para evaluar las estructuras existentes de hormigón de cemento aluminoso (CA).
\end{abstract}

\begin{abstract}
SUMMARY
Potential degradation of concrete structures made of calcium aluminate cement (CAC) is well known and is caused by transformation (conversion) of the thermodynamically metastable into stable calcium aluminate hydrate phases. This recrystallization is influenced by temperature and humidity; the structural degradation of the concrete itself, thus its loss of strength, is strongly related to the pore structure of the hydrated cement paste, the critical parameters being the total volume of pores below $15-20 \mathrm{~nm}$ and the median micropore radius. This constitutes a novel procedure for evaluation of existing CAC concrete structures.
\end{abstract}

PALABRAS CLAVE: conversión, cemento aluminoso, estructura porosa, propiedades

\section{INTRODUCCIÓN}

Los resultados que se presentan en este trabajo se basan en una revisión resumida de estructuras en edificios construidos entre 1920-1957 en Checoslovaquia con cemento aluminoso (CA)(1). La revisión y los estudios experimentales posteriores se hicieron motivados por un serio accidente, con consecuencias mortales, acaecido en 1984. Aunque el uso de CA fue prohibido en 1957 todavía, hoy día, hay numerosas estructuras de hormigón de cemento aluminoso en servicio.
KEY WORDS: conversion, calcium aluminate cement, pore structure, properties

\section{INTRODUCTION}

The presented results are based on a comprehensive review of actual structures built years ago in Czechoslovakia (1920-1957) using calcium aluminate cement (C AC) (1). The review and the subsequent experimental study were prompted by a serious accident in 1984, that led to several fatalities. Although use of (AC was outlawed in 1957, numerous structures with CAC concrete are still in use. 
La revisión realizada ha evidenciado diversos problemas. En primer lugar, aun cuando a través de los valores obtenidos en las medidas de resistencias se desprendía una buena impresión en cuanto a la aparente calidad de las estructuras analizadas, en el estudio no se indicaba el grado de conversión del CA, por lo cual, la vida residual de las estructuras no podía ser estimada con seguridad. En segundo lugar, a causa de su complejidad, tan sólo se hicieron un número limitado de ensayos físico-químicos de la pasta y, por ello, los resultados eran ambiguos y no siempre acordes con los datos de resistencias. Por último, algunas edificaciones realizadas con $\mathrm{C}$ A no están catalogadas como tales, por lo cual continuamente están apareciendo nuevos casos de daños estructurales.

La evaluación de las estructuras de hormigón de cemento aluminoso es, todavía, un problema, especialmente en cuanto a métodos adecuados. El presente trabajo es una contribución sobre algunos nuevos aspectos del problema.

\section{BREVE REPASO A LOS ANTECEDENTES CONOCIDOS}

En la década de los 60 se iniciaron importantes investigaciones sobre diversos aspectos de la durabilidad del hormigón de CA. La relación agua/ cemento, y por ello la densidad de la matriz, fue el primer parámetro encontrado que relacionaba la cinética de conversión de $\mathrm{CAH}_{10}+\mathrm{C}_{2} \mathrm{AH}_{8}$ a $\mathrm{C}_{3} \mathrm{AH}_{6}+$ $\mathrm{AH}_{3}$. Igualmente se observó que el aumento de temperatura incrementaba la velocidad de conversión $(2,3)$. Además se comprobó que la carbonatación y posiblemente también los álcalis, tenían un efecto destructivo $(2,4,5)$. Una recopilación más amplia del mecanismo de hidratación del cemento aluminoso ha sido publicada por Sorrentino y col. (6).

Ya desde el comienzo de aquellos estudios, el mecanismo del proceso de conversión se relacionó con la transformación de los hidratos metastables primarios $\left(\mathrm{CAH}_{10}+\mathrm{C}_{2} \mathrm{AH}_{8}\right)$-formados durante la hidratación del cemento- a hidratos estables, $\mathrm{C}_{3} \mathrm{AH}_{6}+\mathrm{AH}_{3}(3,5,7,8)$. Las reacciones básicas de hidratación son las siguientes:

$$
\begin{gathered}
\mathrm{CA}+10 \mathrm{H}=\mathrm{CAH}_{10} \\
2 \mathrm{CA}+11 \mathrm{H}=\mathrm{C}_{2} \mathrm{AH}_{8}+\mathrm{AH}_{3} \\
3 \mathrm{CA}+12 \mathrm{H}=\mathrm{C}_{3} \mathrm{AH}_{6}+2 \mathrm{AH}_{3}
\end{gathered}
$$

Las mejores propiedades cementicias las tiene el $\mathrm{CAH}_{10}$ formado en la hidratación a temperaturas por debajo de $30^{\circ} \mathrm{C}$. Es también responsable de las elevadas
The review exposed several problems. First of all, although the obtained strengths data gave a good picture of the quality of the relevant structures at the time of the review, they did not reveal the degree of $C A C$ conversion, thus the remaining service life of the structures could not be estimated with certainty. Secondly, because of their complexity, only limited physico-chemical tests of the paste matrix were performed, and the results were ambiguous and not always in line with strength data. Finally, several CAC structures were missed, thus new cases of structural damage are continuously occurring.

Evaluation of CAC concrete structures is still an issue, especially the best testing methodology. In this contribution, some new aspects of the problem are reviewed.

\section{A BRIEF OVERVIEW OF BACKGROUND INFORMATION}

Serious research on the durability aspects of CAC concrete was initiated in the 1960's. Water-to-cement ratio, thus the density of the matrix, was the first condition found to be related to the kinetics of the $\mathrm{CAH}_{10}+\mathrm{C}_{2} \mathrm{AH}_{8}$ to $\mathrm{C}_{3} \mathrm{AH}_{6}+\mathrm{AH}_{3}$ conversion. Similarly increased temperature was found to lead to increased rate of conversion (2,3). Additionally, carbonation in combination with alkalies were found to have deleterious effect $(2,4,5)$. A more comprehensive review of (AC hydration mechanism has been published by Sorrentino et al.(6).

The mechanism of conversion was soon recognized to be related to the transformation of primary metastable hydrates, $\left(\mathrm{CAH}_{10}+\mathrm{C}_{2} \mathrm{~A} \mathrm{H}_{\mathrm{g}}\right)$, formed during the hydration of $C A C$, to stable hydrates $C_{3} A H_{6}+A_{3}$ $(3,5,7,8)$. The basic hydration reactions are as follows:

$$
\begin{gathered}
C A+10 \mathrm{H}=\mathrm{CAH}_{10} \\
2 \mathrm{CA}+11 \mathrm{H}=\mathrm{C}_{2} A \mathrm{H}_{8}+A H_{3} \\
3 \mathrm{CA}+12 \mathrm{H}=\mathrm{C}_{3} A H_{6}+2 A H_{3}
\end{gathered}
$$

The best cementitious properties has the monocalcium aluminate hydrate $\mathrm{CAH}_{10}$ forming at hydration temperatures of up to about $30^{\circ} \mathrm{C}$. It is responsible for 
resistencias iniciales del cemento. $\mathrm{El}$ aluminato dicálcico, $\mathrm{C}_{2} \mathrm{AH}_{8}$, se forma a temperaturas algo más altas, de $28-35^{\circ} \mathrm{C}$; su capacidad ligante es más baja, por lo que el aumento de la proporción de este aluminato conduce a menores resistencias. La reacción [3] se da en procesos por encima de $35^{\circ} \mathrm{C}$ y genera el hexahidrato $\mathrm{C}_{3} \mathrm{AH}_{6}$, que da bajas resistencias. $\mathrm{El}$ hidróxido de aluminio, $\mathrm{AH}_{3}$, no posee ninguna propiedad ligante. Este comportamiento adhesivo diferente puede ser explicado por el diferente proceso de formación de cristales de los distintos hidratos, y por el tamaño y la forma de los mismos, factores que controlan el número de contactos partícula-partícula, responsables éstos, a su vez, de las propiedades cementicias de los sólidos: Más adelante se profundizará en este aspecto.

A causa de su inestabilidad termodinámica, los hidratos metastables se transforman en estables, según:

$$
\begin{aligned}
& 3 \mathrm{CAH}_{10}=\mathrm{C}_{3} \mathrm{AH}_{6}+2 \mathrm{AH}_{3}+18 \mathrm{H} \\
& 3 \mathrm{C}_{2} \mathrm{AH}_{8}=\mathrm{C}_{3} \mathrm{AH}_{6}+\mathrm{AH}_{3}+9 \mathrm{H}
\end{aligned}
$$

Las reacciones de conversión [4] y [5] son procesos naturales; no pueden ser eludidos, pero se puede influir sobre sus cinéticas. Como consecuencia de estas reacciones se produce un incremento de la porosidad, ello es debido, por una parte, a la diferencia en la densidad de los productos iniciales y finales y por otra a la formación de agua como un producto de la reacción $\mathrm{El}$ grado de conversión se expresa generalmente como sigue (8):

$$
\begin{aligned}
& \mathrm{Dc}=\frac{\mathrm{C}_{3} \mathrm{AH}_{6} \times 100}{\mathrm{C}_{3} \mathrm{AH}_{6}+\mathrm{CAH}_{10}} \\
& \mathrm{Dc}=\frac{\mathrm{AH}_{3} \times 100}{\mathrm{AH}_{3}+\mathrm{CAH}_{10}}
\end{aligned}
$$

La ecuación [7] se considera más adecuada ya que refleja también los cambios de composición en los productos de reacción causados por la carbonatación posterior sobre el hexahidrato estable.

Es de lamentar que esta expresión del grado de conversión no clarifique suficientemente los efectos observados sobre el hormigón de CA en estructuras, porque, como se puede comprobar, no hay una correlación lineal entre el grado de conversión y la resistencia. Este es un factor importante a tener en cuenta al tratar la rehabilitación de estructuras hechas con hormigón de CA high early strength of $C A C$. Dicalcium aluminate hydrate, $C_{2} A H_{8}$, forms at somewhat higher temperatures of $28-35^{\circ} \mathrm{C}$; its binding capacity is lower, thus increased proportion of this hydrate leads to lower strength. Reaction [3] is typical for processes above about $35^{\circ} \mathrm{C}$ and the resulting hexahydrate $C_{3} A H_{6}$ gives only low strength. Aluminum hydroxide, $A H_{3}$, does not posses any cementitious properties. This can be best explained by the differences in the crystal habit of the formed hydrates, the size and shape of which controls the number of particle-to-particle contacts resonsible for the cementitious properties; more on this issue later.

Because of thermodynamical instability, the matastable hydrates convert to stable ones:

$$
\begin{aligned}
& 3 C_{10}=C_{3} A H_{6}+2 A H_{3}+18 H \quad[4] \\
& 3 C_{2} A H_{8}=C_{3} A H_{6}+A H_{3}+9 H \quad[5]
\end{aligned}
$$

Transformation reactions [4] and [5] are natural processes; they cannot be eliminated but their kinetics can be influenced. Because of the differences in the density of the initial and final product, but also because one of the transformation reaction products is water, they lead to increased porosity. The degree of transformation is usually expressed as follows (8):

$$
\begin{gathered}
D c=\frac{C_{3} A_{6} \times 100}{C_{3} A H_{6}+C A H_{10}} \\
D c=\frac{A H_{3} \times 100}{A H_{3}+C A H_{10}}
\end{gathered}
$$

Equation [7] is considered to be more accurate because it reflects also on changes in composition of reaction products caused by subsequent carbonation of the stable hexahydrate.

Unfortunately, such expression of the degree of conversion does not completely clarify the issue of actual state of the CAC concrete or structure because, as will be shown, there is no linear correlation between the degree of conversion and strength. This is an important fact to take into consideration when rehabilitation of an CAC concrete structure is being considered. 


\section{METODOLOGÍA EXPERIMENTAL}

La mayor parte de los trabajos experimentales se realizaron sobre muestras extraídas de cimentaciones realizadas con hormigón de $\mathrm{CA}$ en edificaciones del año 1922. Se tomaron muestras a las siguientes profundidades:

$\begin{array}{cc}\text { Muestra } & \text { Profundidad (m) } \\ 1 & 2,0 \\ 2 & 1,5 \\ 3 & 1,0 \\ 4 & 0,7 \\ 5 & 0,4\end{array}$

La muestra 1 se dividió en dos fracciones, representando una de ellas la parte interior de la pasta, que permanecía aún muy dura (¡Muestra 1a: con resistencias por encima de $70 \mathrm{MPa}$ !) y la otra el material que queda después de la separación. Aunque las resistencias fueron determinadas sobre probetas de alrededor de un $\mathrm{cm}^{3}$, utilizando un esclerómetro de torsión, estos resultados se consideran suficientemente buenos.

Se ensayaron, además, otras muestras de hormigones $\mathrm{CA}$, extraídas tanto de edifícios afectados como preparadas en el laboratorio, de acuerdo a la metodología que a continuación se expone.

Se utilizaron los siguientes procedimientos experimentales (1):

* Análisis químico rutinario

* Análisis de la estructura porosa por porosimetría de mercurio (Carlo Erba, Milán)

*Microscopía Electrónica, SEM) Stereocsan,

Cambridge Scientific Instruments, Ltd.)

*Difracción de Rayos X, QXRD (Philips, goniómetro PW 1050).

*Análisis Térmicos complejos: ATD y ATG

(Derivatógrafo OD 102)

\section{RESULTADOS EXPERIMENTALES}

La composición química del hormigón, determinada por machaqueo y separación semi-cuantitativa de las muestras (dos fracciones: una mayoritaria de árido y la otra mayoritaria de la pasta), indica que el cemento utilizado fue aluminoso, con un contenido en $\mathrm{SiO}_{2}$ algo más alto del habitual. La composición de todas las muestras fue la misma.

De igual forma, los resultados obtenidos por difracción de rayos $\mathrm{X}$ revelan que se forman los mismos productos

\section{EXPERIMENTAL METHODOLOGY}

Most of the experimentation was performed on samples removed from $C A C$ concrete foundations of a building constructed in 1922. There were removed from the depths of:

$\begin{array}{cc}\text { Sample } & \text { Depth (meters) } \\ 1 & 2.0 \\ 2 & 1.5 \\ 3 & 1.0 \\ 4 & 0.7 \\ 5 & 0.4\end{array}$

Sample 1 was split into two fractions, representing the very hard remnants of the original paste (Sample la: strength above $70 \mathrm{MPa}$ !) and the material remaining after separation, respectively. Although the strengths were measured on samples of about a $\mathrm{cm}^{3}$, using torsion sclerometry, the results are considered to be dependable.

Additional CAC concrete samples, taken both from affected buildings and prepared in the laboratory, were tested; details will be given in the text

The following experimental procedures were used (1):

*Routine chemical analyses

*Pore structure analysis by mercury porosimetry (Carlo Erba Milano)

*Scanning Electron Microscopy, SEM (Stereocsan, Cambridge Scientific Instruments, Ltd.)

*X-ray diffraction analysis, $Q X R D$ (Phillips, $P W 1050$ goniometer)

*Complex thermal analysis: DTA and TGA

(Derivatograph OD 102)

\section{EXPERIMENTAL DATA}

Chemical composition of the concrete, determined from crushed and semi-quantitatively separated core samples (two fractions: mostly aggregate \& predominantly cement plus hydrates), revealed that the cement used was $C A C$ with somewhat higher than usual $\mathrm{SiO}_{2}$ content. The composition was the same in all samples.

Similarly, X-ray diffraction analysis revealed the same reaction products in all samples. The primary reaction 
de reacción en todas las muestras. Los mayoritarios son el $\mathrm{CAH}_{10}$ y el $\mathrm{C}_{2} \mathrm{AH}_{8}$ cuya proporción va disminuyendo paulatinamente en las muestras, desde la 1a hasta la 5 (a través de la 1b, 2, 3 y 4). Las mayores cantidades de fases convertidas $\left(\mathrm{C}_{3} \mathrm{AH}_{6}+\mathrm{AH}_{3}\right)$ fueron detectadas en las muestras 4 y 5 , disminuyendo en las muestras desde la $3,2,1 \mathrm{~b}$ a la $1 \mathrm{a}$. Se detectaron también otras fases relacionadas con los áridos utilizados, en particular cuarzo. Se observaron por DRX pequeñas cantidades de calcita y vaterita en las muestras 4 y 5 . Estas son fases secundarias formadas por carbonatación de los productos de hidratación.

Los análisis termogravimétricos y de ATD confirman los resultados obtenidos por DRX. A partir de la evaluación de las cuatro señales endotérmicas y relacionando sus pérdidas de peso, se han obtenido los siguientes grados aproximados de conversión (1):

\section{$\underline{\text { Muestra }}$}

\section{Grado de Conversión}

(por ciento, a partir eq.[7])

$\begin{array}{lc}1 \mathrm{a} & 19 \\ 1 \mathrm{~b} & 24 \\ 2 & 26 \\ 3 & 29 \\ 4 & 41 \\ 5 & 42\end{array}$

Mientras que la cantidad de $\mathrm{CAH}_{10}$ disminuye desde alrededor del $27 \%$ en la muestra la hasta el $17 \%$ en la muestra 5, el crecimiento correspondiente de $\mathrm{C}_{3} \mathrm{AH}_{6}$ fue desde el $6 \%$ en la muestra 1a hasta el $12 \%$ en la muestra 5. La proporción de $\mathrm{CaCO}_{3}$ paralelamente, crecía desde el 3,2\% para la muestra la, hasta el $8,6 \%$ en la muestra 5. Debido a las suposiciones hechas en los cálculos, la proporción real de $\mathrm{C}_{3} \mathrm{AH}_{6}$ y el grado de conversión eran probablemente algo más bajos. Los detalles se dan en la Tabla I.

La microscopía electrónica de barrido se utilizó para comparar las morfologías de los productos de hidratación y de conversión en las muestras. En resumen, la muestra la estaba constituida en su mayor parte por cristales muy pequeños e irregulares de $\mathrm{CAH}_{10}$ mezclados con menor cantidad de mayores cristales hexagonales de $\mathrm{C}_{2} \mathrm{AH}_{8}$. Partículas tan pequeñas de $\mathrm{CAH}_{10}$, casi de tipo coloidal, permiten la formación de morfologías compactas y de baja porosidad, en donde es posible que se establezcan numerosos contactos entre partícula y partícula (enlace de partícula (9)). No se observó ninguna señal de conversión (Figura 1).

Por el contrario, las muestras 3 y 4 , pero sobre todo la muestra 5 tienen bajas proporciones de $\mathrm{CAH}_{10} \mathrm{y}$ products found were $C A H_{10}$ and $C_{2} A H_{8}$, in decreasing amounts from Sample la, through $1 b, 2,3,4$, to 5 . The largest amounts of converted phases, $C_{3} A H_{6}+A H_{3}$, were detected in samples 4 and 5 , decreasing through samples 3, 2, Ib, to la. Most other detected phases were related to the aggregate used, primarily quartz. Small amounts of calcite and vaterite, found by $Q X R D$ in samples 4 and 5, are secondary phases formed by carbonation of the hydration products.

Thermogravimetric and DTA data confirmed those obtained by QXRD. Based on evaluation of four distinct endotherms and related weight losses, the following approximate degrees of conversion were obtained (1):

$\begin{array}{cr}\text { Sample } & \text { Degree of Con } \\ & \text { (percent, per } \\ 1 a & 19 \\ 1 b & 24 \\ 2 & 26 \\ 3 & 29 \\ 4 & 41 \\ 5 & 42\end{array}$

Whereas the amount of $C A H_{10}$ decreased from about 27 percent in Sample la to 17 percent in Sample 5, the corresponding increase in $C_{3} A H_{6}$ was from about 6 percent in Sample la to 12 percent in Sample 5. The amount of $\mathrm{CaCO}_{3}$, at the same time, increased from 3.2 percent for Sample la to 8.6 percent in Sample 5. Because of the assumptions made in the calculation, the actual amount of $C_{5} A H_{6}$ and degree of conversion were most probably somewhat lower. Details are given in Table I.

Scanning Electron Microscopy was used to compare the morphologies of the hydration and conversion products in the samples. Briefly, Sample la consisted mostly of minute, irregular crystallites of $\mathrm{CAH}_{10}$ mixed with lesser amount of larger hexagonal crystals of $C_{2} A H_{g}$. The fine, almost colloidal size particles of CAH ${ }_{10}$ lead to a compact, low-porosity morphology with numerous particle-to-particle contacts (particle bridging (e.g.,9)). No sign of conversion was observed (Figure 1).

In contrast, samples 3 and 4, but mostly Sample 5, show diminished amounts of $\mathrm{CAH}_{10}$ and large amounts 
TABLA I (TABLE I)

Resultados de los análisis termogravimétricos y cálculo de los grados de conversión (Results of thermogravimetric analyses and calculated degrees of conversion)

\begin{tabular}{|c|c|c|c|c|c|c|c|}
\hline & & \multicolumn{6}{|c|}{ Muestra de hormigón (Concrete sample) } \\
\hline & & $1 \mathrm{a}$ & $1 b$ & 2 & 3 & 4 & 5 \\
\hline \multicolumn{8}{|l|}{$\begin{array}{l}\text { Pérdida al fuego: } \\
\text { (ignition loss): }\end{array}$} \\
\hline hasta (up to) $200^{\circ} \mathrm{C}$ & $\%$ & 14,6 & 13,6 & 12,8 & 11,6 & 9,4 & 9,1 \\
\hline $200-400^{\circ} \mathrm{C}$ & $\%$ & 1,8 & 2,3 & 2,4 & 3,6 & 3,5 & 3,5 \\
\hline $400-700^{\circ} \mathrm{C}$ & $\%$ & 1,3 & 1,3 & 1,2 & 1,2 & 1,1 & 1,0 \\
\hline $700-1.000^{\circ} \mathrm{C}$ & $\%$ & 1,4 & 1,3 & 1,7 & 2,5 & 3,6 & 3,8 \\
\hline $\begin{array}{l}\text { Pérdida al fuego total } \\
\text { (Total ignition loss) }\end{array}$ & $\begin{array}{l}\% \\
\%\end{array}$ & 19,1 & 18,5 & 18,1 & 17,9 & 17,6 & 17,4 \\
\hline \multicolumn{8}{|l|}{$\begin{array}{l}\text { Cantidad aproximada: } \\
\text { (Approximate amount): }\end{array}$} \\
\hline $\mathrm{CAH}_{10}$ & $\%$ & 27,4 & 25,5 & 24,0 & 21,8 & 17,6 & 17,1 \\
\hline $\mathrm{C}_{3} \mathrm{AH}_{6}$ & $\%$ & 6,3 & 8,0 & 8,4 & 9,1 & 12,3 & 12,3 \\
\hline $\mathrm{CaCO}_{3}$ & $\%$ & 3,2 & 2,9 & 3,8 & 5,7 & 8,2 & 8,6 \\
\hline \multicolumn{8}{|l|}{$\begin{array}{l}\text { Grado de conversión } \\
\text { aproximado } \\
\text { (Aproximate degree of } \\
\text { conversion) }\end{array}$} \\
\hline (per. eq. 5.) & $\%$ & 18,7 & 23,9 & 25,9 & 29,4 & 41,1 & 41,8 \\
\hline
\end{tabular}

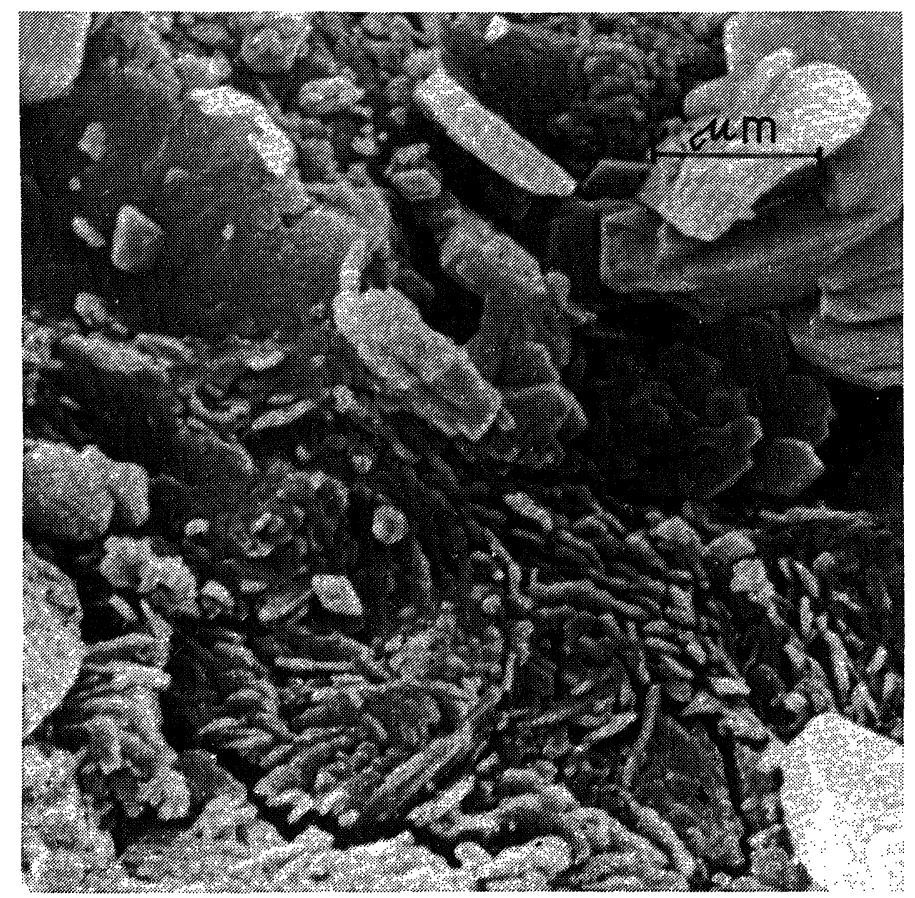

Fig. 1.- SEM. Microestructura del hormigón \# 1a. Superficie de fractura. Fig. 1.- SEM. View of concrete \# la microstructure. Fracture surface. 
grandes cantidades de cristales de $\mathrm{C}_{3} \mathrm{AH}_{6}$ de tamaño hasta 100 veces superior a los de $\mathrm{CAH}_{10}$, junto con alguna partícula de $\mathrm{CaCO}_{3}$. La estructura del material es más abierta con áridos de gran tamaño claramente visibles y una elevada porosidad (Figura 2). of upto 100x larger $\mathrm{C}_{3} \mathrm{AH}_{6}$ particles plus some $\mathrm{CaCO}{ }_{3}$ The structure of the material is more open, with clearly visible aggregations of larger particles plus increased porosity (Figure 2).

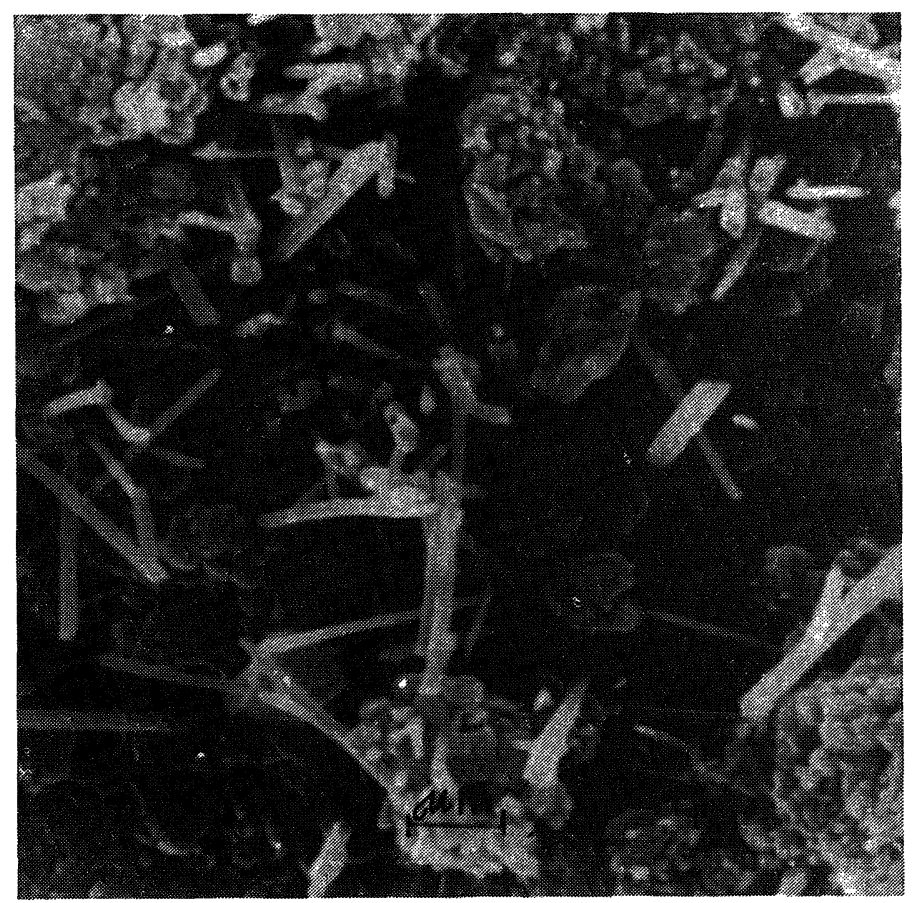

Fig. 2.- SEM. Microestructura del hormigón \# 5. Superficie de fractura.

Fig. 2.- SEM. View of concrete \# 5 microstrcture. Fracture surface.

Los resultados de las medidas porosimétricas se presentan en la Tabla II. Muestran claramente las alteraciones en los tamaños de los poros causadas por el proceso de conversión. Cantidades relativas de poros con diferentes radios se muestran en la Figura 3.

\section{DISCUSIÓN DE RESULTADOS}

\section{Relación entre Proceso de Conversión y Estructura Porosa}

La porosidad de una matriz cementicia es, de hecho, una réplica de la estructura cristalina de sus componentes y refleja la distribución de los tamaños, formas y morfologías de sus componentes sólidos, así como del tipo y "calidad" de la unión que existe entre dichos sólidos. Las cuestiones en torno a la formación de uniones, cualidades cementicias y "capacidad adherente" han sido marginalmente exploradas, sin embargo sí se dispone de alguna información, entre otras los trabajos de Rehbinder y Taylor (ejem. 9,12, 13, 14). La calidad de las uniones cementicias depende, entre otras cosas, de la cantidad de los contactos y del
The results of the porosimetric measurements are given in Table II. The results clearly show the changes in the relative pore sizes caused by the conversion of the reaction products. The relative amounts of pores with different pore radii are given in Figure 3.

\section{DISCUSSION OF RESULTS}

\section{Conversion versus Pore Structure}

The pore structure of a cementitious matrix is in fact a replica of its solid crystalline structure and reflects the size distribution, shape and morphology of its solid components, as well as the "quality" of the bond. The issues of bond formation, cementitious quality, and "binding capacity" are only marginally explored issues, but some information is available, among others, in works of Rehbinder and Taylor (e.g., 9, 12, 13, 14). The quality of the cementitious bond depends, among others, on the amount of contacts, or degree of "bridging", between the hydrated particles. This, in turn, depends on size, shape, surface area, surface 


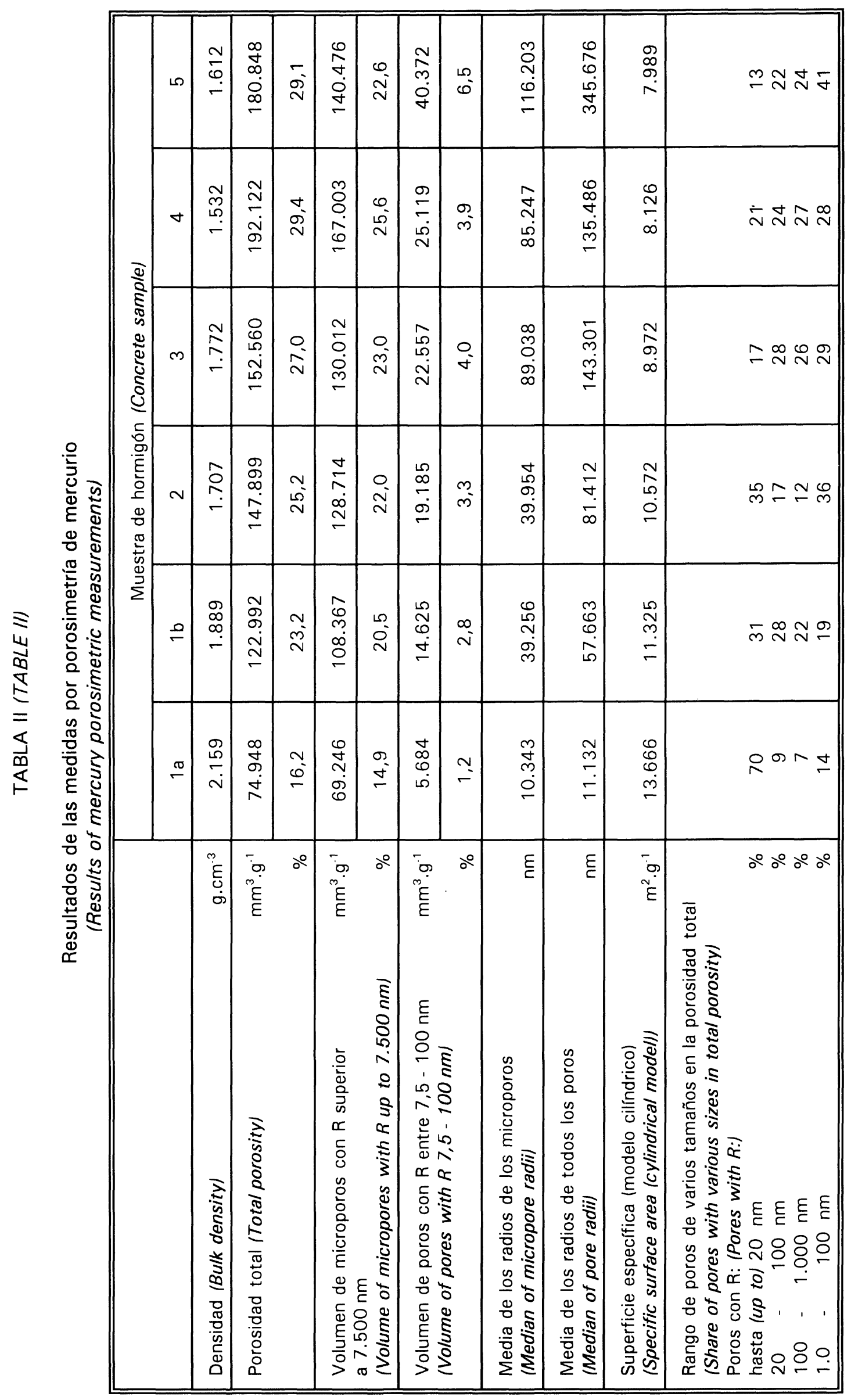




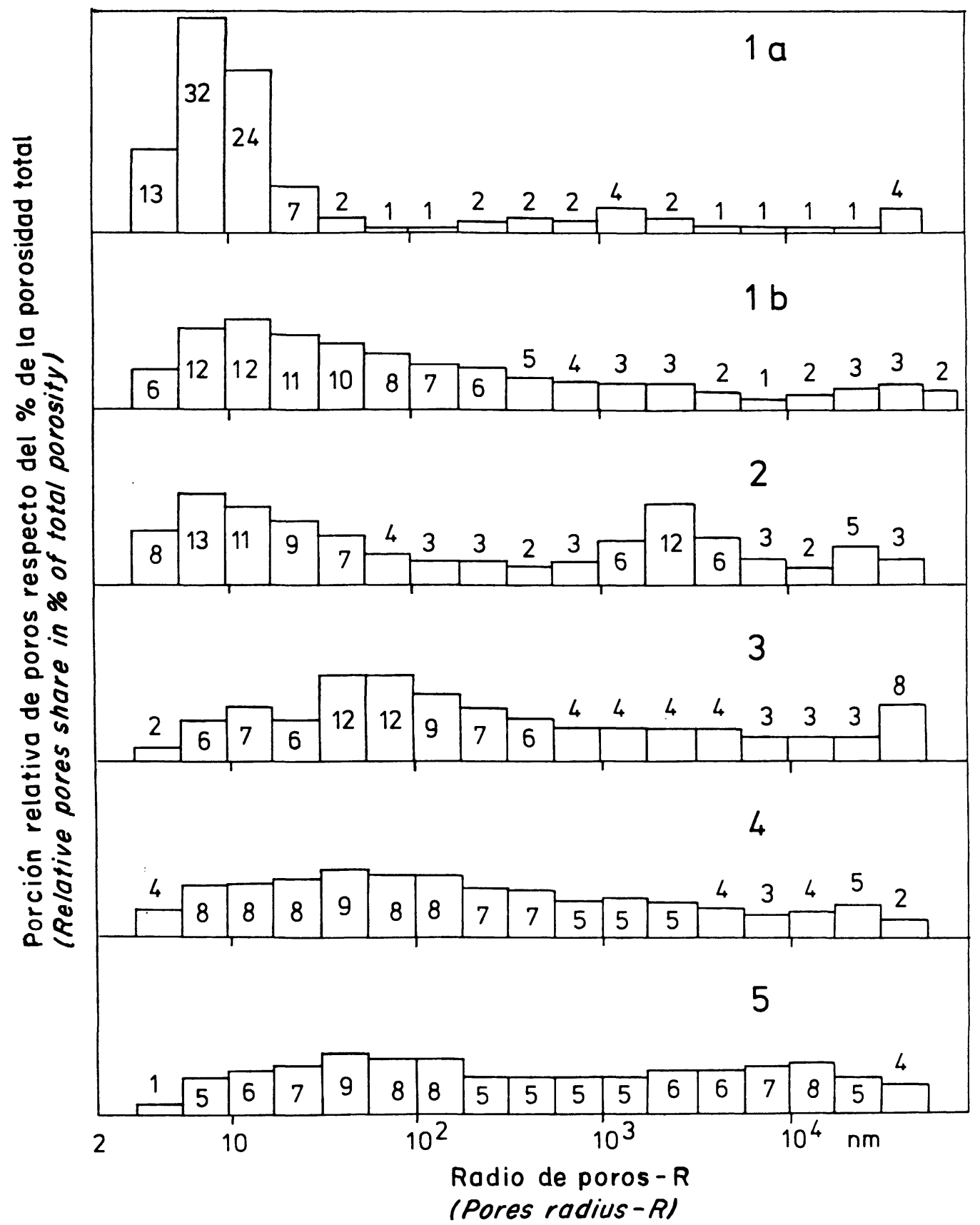

Fig. 3.- Distribución del volumen de microporos como una función del radio de los microporos.

Fig. 3.- Distribution of micropore volume as a function of micropore radius.

grado de unión entre las partículas hidratadas. Esto, por otra parte, depende del tamaño, forma, superficie específica y propiedades superficiales de las partículas. La conversión del CA es un proceso de disolución y posterior precipitación caracterizado por cambios en la estructura cristalina, en el tamaño y en la forma de los productos iniciales de la hidratación. La matriz inicial de $\mathrm{CAH}_{10}$ y $_{2} \mathrm{AH}_{8}$ se convierte en una matriz de $\mathrm{C}_{3} \mathrm{AH}_{6}$ y $\mathrm{AH}_{3}$, con diferentes propiedades. La regresión de resistencias es, entonces, consecuencia de un cambio en la estructura cristalina.

La Tabla III resume los resultados obtenidos al analizar muestras de cemento aluminoso, obtenidas tanto en properties of the particles. Conversion of CAC is a process of dissolution and subsequent precipitation characterized by changes in crystal structure, size, and shape of the primary hydration products. The original matrix of $C A H_{10}$ and $C_{2} A H_{8}$ converts to a matrix of $\mathrm{C}_{3} \mathrm{AH}_{6}$ and $\mathrm{AH}_{3}$, having different properties. The strength regression is thus a result of changes in crystalline structure.

Table III summarizes the data obtained by analyzing both laboratory and field samples made with (AC'. The 


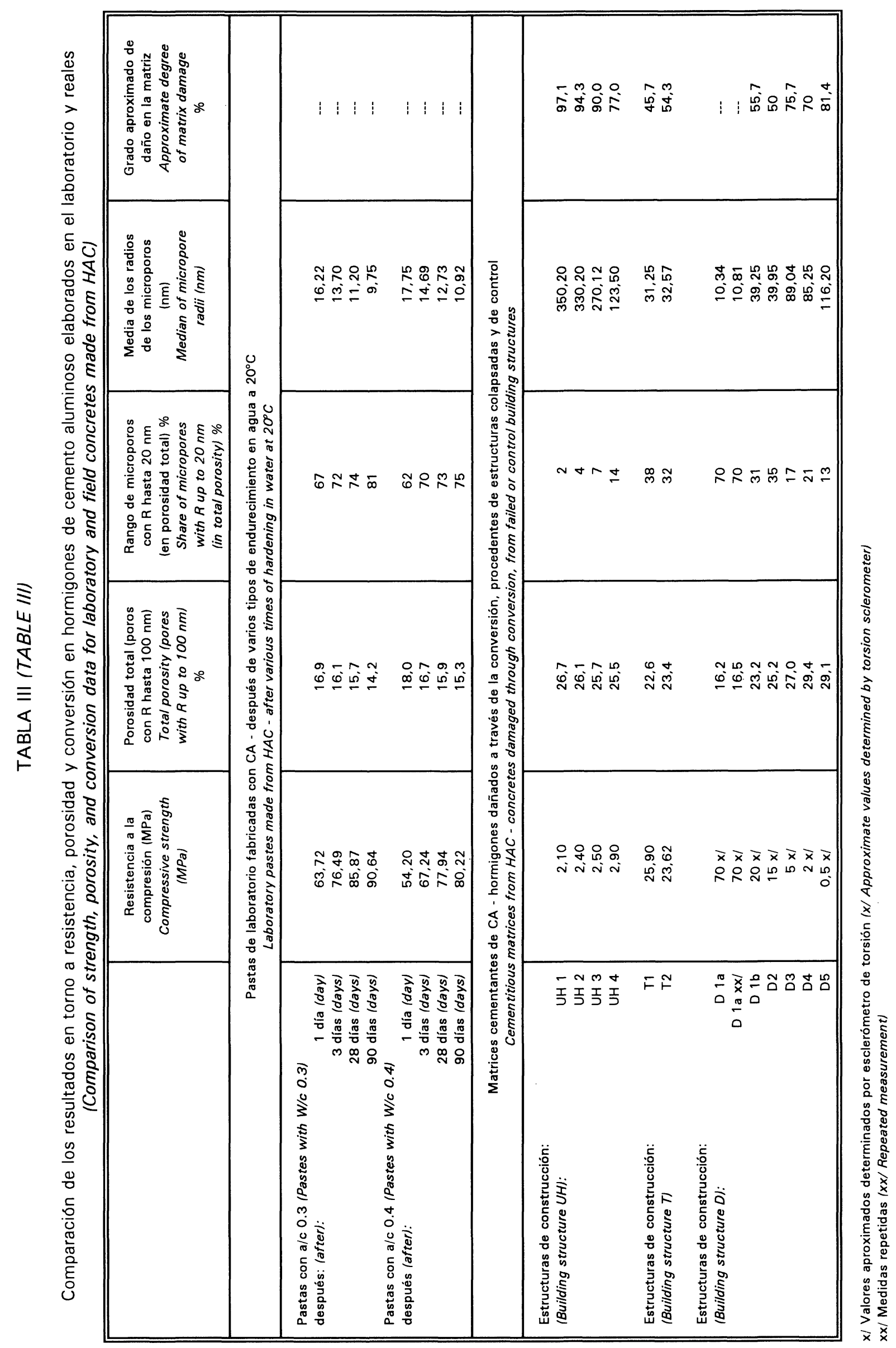


laboratorio como en campo. Los datos muestran que la matriz de $\mathrm{CAH}_{10}$ y $\mathrm{C}_{2} \mathrm{AH}_{8}$ está compuesta de partículas coloidales a microcoloidales de $\mathrm{CAH}_{10}$ formando una densa matriz de baja porosidad (16-17\%) y alta resistencia (> $50 \mathrm{MPa}$ ). Alrededor del $70 \%$ de la porosidad está en forma de microporos con radios por debajo de $20 \mathrm{~nm}$, con un tamaño medio de poro inferior a $15 \mathrm{~nm}$.

Por el contrario, la matriz de $\mathrm{C}_{3} \mathrm{AH}_{6}$ y $\mathrm{AH}_{3}$ está formada por grandes cristales, de tamaño dos órdenes de magnitud superiores, formando una estructura abierta ( $30 \%$ de porosidad) con resistencias generalmente inferiores a $5 \mathrm{MPa}$. Los radios de los poros son, en su mayoría, superiores a $100 \mathrm{~nm}$; los inferiores a $20 \mathrm{~nm}$ prácticamente no existen. En consecuencia, la conversión se caracteriza por un aumento de la porosidad, una disminución de la resistencia y una menor proporción de microporos con radios inferiores a $20 \mathrm{~nm}$. Esto se muestra esquemáticamente en la Figura 4. data show that the matrix of $\mathrm{CAH}_{10}$ and $\mathrm{C}_{2} A \mathrm{H}_{8}$ composed of colloidal to microcrystalline particles of $\mathrm{CAH}_{10}$ forming a dense matrix of low porosity (16-17 percent) and high strength (> $50 \mathrm{MPa}$ ). About 70 percent of the porosity is in the form of pores having radii below $20 \mathrm{~nm}$, with the pore radius median being below $15 \mathrm{~nm}$.

In contrast, the $\mathrm{C}_{3} \mathrm{AH}_{6}+\mathrm{AH}_{3}$ matrix consists of crystallites larger by two orders of magnitude, forming an open structure (30\% porosity) with strength usually below $5 \mathrm{MPa}$. The pore radii are mostly above $100 \mathrm{~nm}$; pores with radii below $20 \mathrm{~nm}$ are essentially nonexistent. Consequently, the conversion is characterized by increasing porosity, decreasing strength, and a drop in proportion of micropores with radii below $20 \mathrm{~nm}$. This is schematically shown in Figure 4.

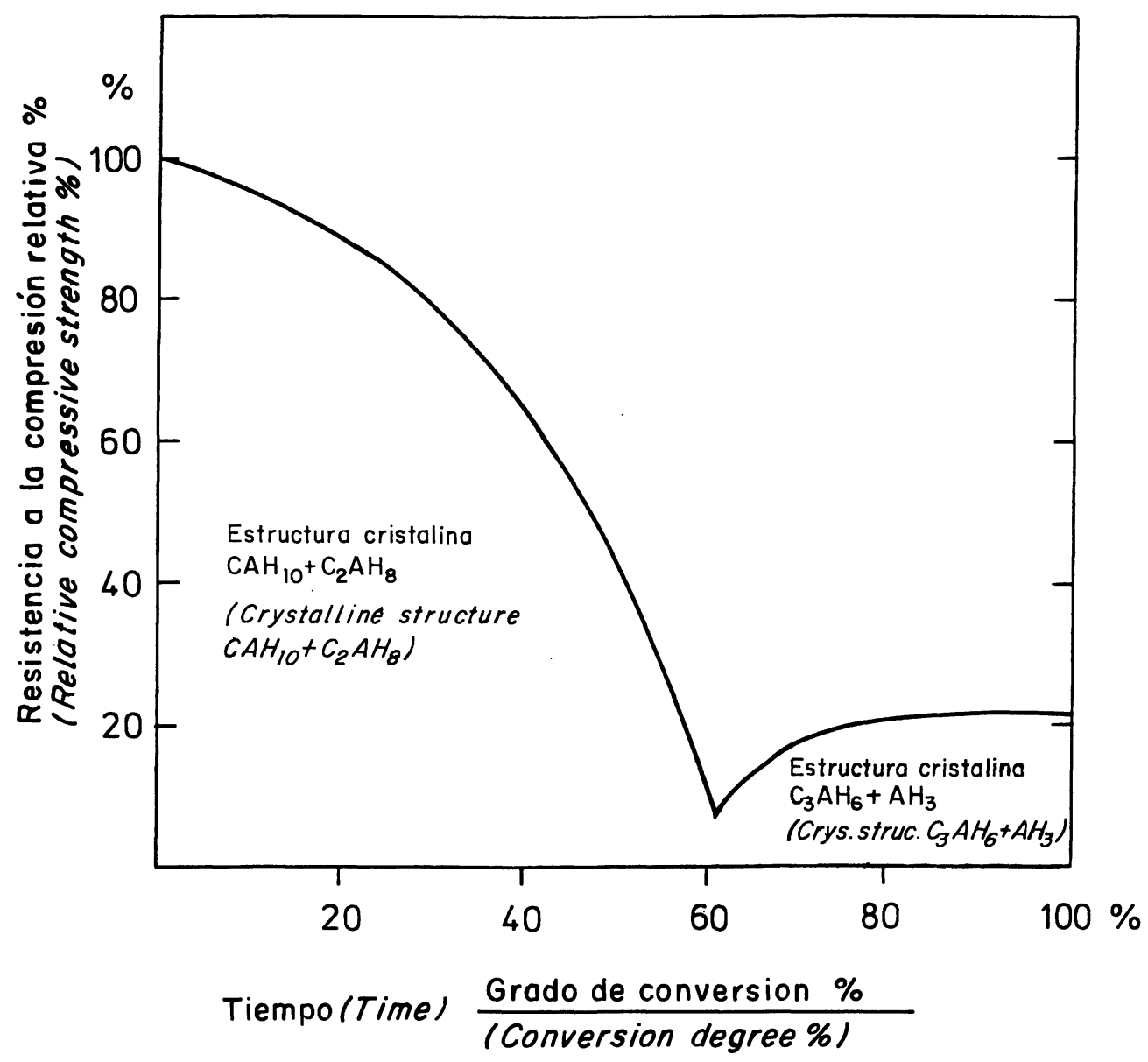

Fig. 4.- Resistencia a la compresión relativa como una función del grado de conversión.

Fig. 4.- Relative compressive strength as a function of the degree of conversion. 
Evaluación del Grado del Daño a partir de los Datos de Porosidad Estructural

La conversión desde los hidratos iniciales hasta los productos de esa conversión conduce a un incremento de la porosidad total de la matriz debido a una disminución en el conjunto del volumen de las fases sólidas; esto es una consecuencia de la mayor densidad de los productos que se generan en la conversión:

$\begin{array}{lll}\mathrm{CAH}_{10} & - & \text { ca. } 1,75 \mathrm{~g} \cdot \mathrm{cm}^{-3} \\ \mathrm{C}_{2} \mathrm{AH}_{8} & - & \text { ca. } 1,95 \mathrm{~g} \cdot \mathrm{cm}^{-3} \\ \mathrm{C}_{3} \mathrm{AH}_{6} & - & \text { ca. } 2,53 \mathrm{~g} \cdot \mathrm{cm}^{-3} \\ \mathrm{AH}_{3} & - & \text { ca. } 2,45 \mathrm{~g} \cdot \mathrm{cm}^{-3}\end{array}$

La conversión completa del $\mathrm{CAH}_{10}$ incrementa la porosidad en un $55 \%$ y la del $\mathrm{C}_{2} \mathrm{AH}_{8}$ alrededor de un $30 \%$. En un cemento aluminoso constituido tan sólo con esos compuestos, la porosidad podría aumentar en un $42-47 \%$. Desgraciadamente, la porosidad real de la matriz de cemento aluminoso deteriorada no es un criterio suficiente para estimar el grado de daño y de conversión. Ello es debido a que, normalmente, se desconoce la porosidad total que existía en la matriz original de cemento aluminoso antes de iniciar la conversión, y es dificil de estimar.

Parece que un método mejor es la estimación del porcentaje de microporos con un radio inferior a 20 $\mathrm{nm}$. Los resultados demuestran que la mayor parte de las matrices no degradadas tienen por encima de un $70 \%$ de tales poros, con un límite inferior en el $65 \%$. Por ello, es posible calcular el grado de deterioro de la matriz a partir de la presencia de poros con radio inferior a $20 \mathrm{~nm}$, con el $65 \%$ como valor más alto y $0 \%$ como más bajo. Este criterio fue utilizado para la confección de la Tabla II.

Otra opción es caracterizar los daños de la matriz a partir de del incremento del radio medio de los poros superiores a $15 \mathrm{~nm}$. Dado que este valor no es enteramente una función del porcentaje de poros con radio inferior a $20 \mathrm{~nm}$, se puede considerar a esta opción como secundaria. La Figura 5 muestra la disminución en el porcentaje del radio de los poros por debajo del límite del $65 \%$ y las 5 etapas de deterioro de la matriz en función a la media de los radios de los poros. La Tabla IV resume las 5 etapas propuestas que caracterizan la degradación.

\section{Relación entre el Grado de Conversión y el Daño}

Los termogramas analizados así como los valores de la
Evaluation of the Degree of Damage on the Basis of Pore Structure Data

Conversion from primary hydrates to the conversion products leads to an increase in total porosity of the matrix due to an overall decrease in the volume of solid phases; this is a consequence of much higher density of the conversion products:

$$
\begin{array}{lll}
\mathrm{CAH}_{10} & - & \text { ca. } 1.75 \mathrm{~g} \cdot \mathrm{cm}^{-3} \\
\mathrm{C}_{2} A H_{8} & - & \text { ca. } 1.95 \mathrm{~g} \cdot \mathrm{cm}^{-3} \\
\mathrm{C}_{3} A H_{6} & - & \text { ca. } 2.53 \mathrm{~g} \cdot \mathrm{cm}^{-3} \\
\mathrm{AH}_{3} & - & \text { ca. } 2.45 \mathrm{~g} \cdot \mathrm{cm}^{-3}
\end{array}
$$

Complete conversion of $\mathrm{CAH}_{10}$ increases the porosity by 55 percent; that of $C_{2} A H_{8}$ by about 30 percent. In a CAC composed of only these two phases the porosity would increase by about 42-47 percent. Unfortunately, the actual porosity of the damaged matrix is not a sufficient criterion for estimation of the degree of damage and conversion because the total porosity of the original CAC matrix, prior to the initiation of the conversion, is usually unknown and is difficult to estimate.

It seems that a better method is estimation of the percentage of micropores having a pore radius below $20 \mathrm{~nm}$. Results show that most undamaged matrices have above 70 percent of such pores, with the lower limit being 65 percent. Thus one can calculate the degree of matrix deterioration from the presence of pores below $20 \mathrm{~nm}$ radius, with 65 percent being the maximum, 0 percent the minimum. This method was used in evaluation of data presented in Table II.

Another option is to characterize the matrix damage by the increase in median pore radius above $15 \mathrm{~nm}$. Because this value is not entirely a function of the percentage of pores with radii below $20 \mathrm{~nm}$, this option is considered to be a secondary one. An approximate relationship is presented in Figure 5, showing the decrease of the percentage of pore radii below the 65 percent limit and the 5 steps of matrix deterioration as related to the median pore radius. Table IV summarizes the proposed 5-step damage characterization.

Relationship Between the Degrees of Conversion and Damage

Previously presented thermographic, pore structure 


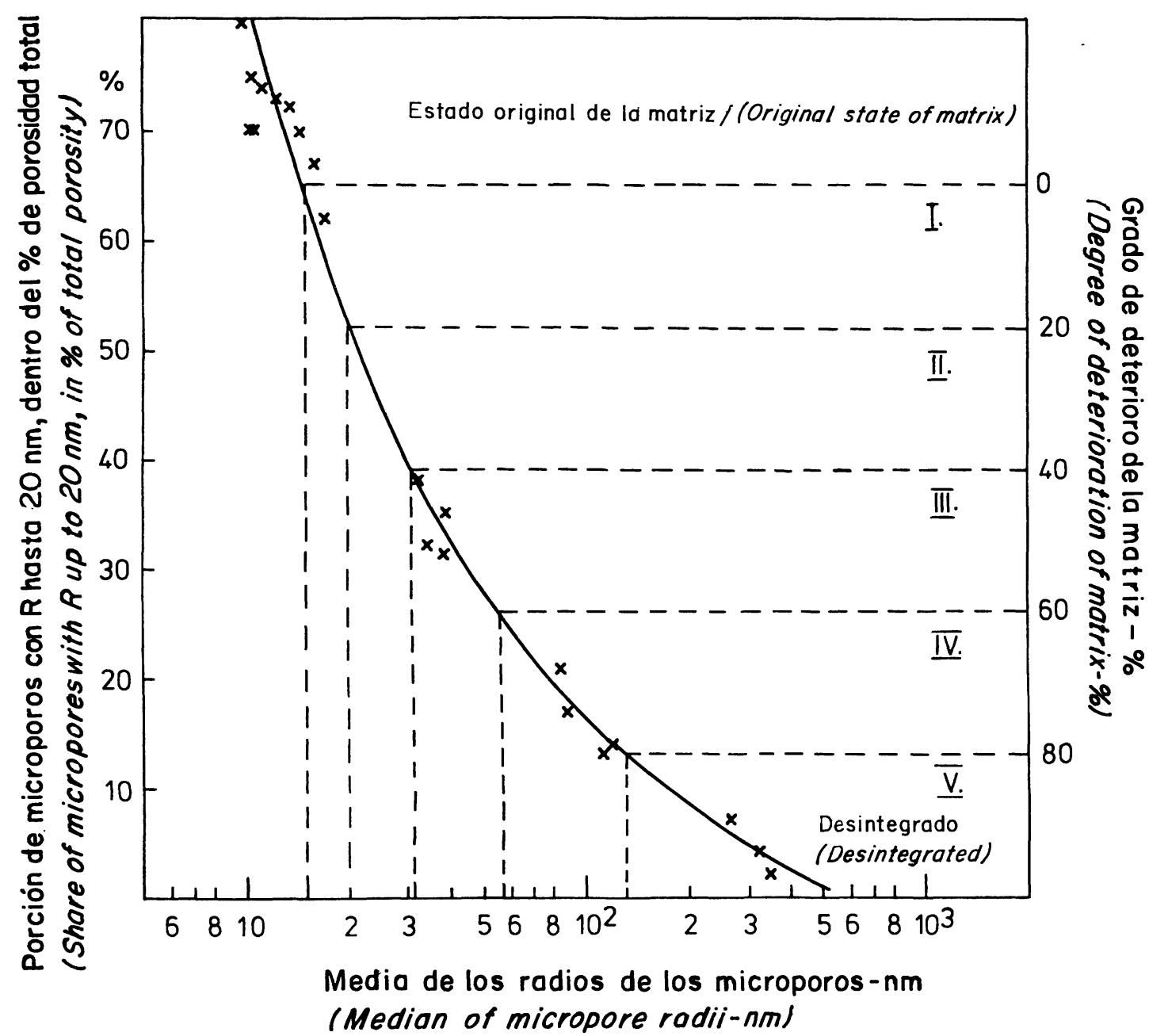

Fig. 5.- Relación entre el porcentaje de microporos por debajo de $20 \mathrm{~nm}$, la media del radio de los microporos y el grado de deterioro estructural.

Fig. 5.- Relationship between the percentage of micropores below nm, the median micropore radius, and the degree of structural deterioration.

estructura porosa en los hormigones y de sus resistencias, demuestran que el grado de conversión y el daño en los hormigones no se pueden relacionar de forma sencilla; si parece que se podrá obtener una mayor infcimación a través de la estructura porosa de la pasta.

Por ejemplo, la muestra la presentó alrededor del 19\% de conversión sin un daño evidente en la estructura de la pasta, $\mathrm{CAH}_{10}+\mathrm{C}_{2} \mathrm{AH}_{8}$. Se cree que pequeñas cantidades de $\mathrm{C}_{3} \mathrm{AH}_{6}$ y $\mathrm{AH}_{3}$ se formaron ya durante la hidratación del cemento y no como resultado de la conversión; no produciendo, por tanto, ningún deterioro. Recíprocamente, en las muestras 4 y 5 el grado de conversión calculado era del $41 \%$, pero el grado de deterioro estimado estaba en el $70-80 \%$, con and strength results show that the relationship between the degree of conversion and the degree of damage is not a simple one, and that much better picture can be obtained by considering the paste pore structure.

For example, sample la exhibited about 19 percent conversion without visible damage to the structure of the $C A H_{10}+C_{2} A H_{6}$ paste. It is believed that small amounts of $\mathrm{C}_{3} \mathrm{AH}_{6}$ and $\mathrm{AH}_{3}$ phases formed already during the hydration of CAC and were not the result of conversion; consequently, they did not result in damage. In contrast, in samples 4 and 5 , the degree of conversion was found to be about 41 percent but the corresponding degree of damage was 70 to 80 percent, 
Deterioro estructural como una función del volumen de microporos inferiores a $20 \mathrm{~nm}$ y de la media

del radio de los poros

(Structural damage as a function of micropore volume below $20 \mathrm{~nm}$ and median pore radius)

\begin{tabular}{|c|c|c|}
\hline $\begin{array}{l}\text { Porción de microporos con } \\
\text { radio hasta } 20 \mathrm{~nm} \text { del } \% \text { de la } \\
\text { porosidad total } \\
\text { (Share of micropores with } \\
\text { radius up to } 20 \mathrm{~nm} \text { in } \% \text { of } \\
\text { total porosity) }\end{array}$ & $\begin{array}{l}\text { Media de los radios de los } \\
\text { microporos en } \mathrm{nm} \\
\text { (Median of micropoore radii } \\
\text { in } \mathrm{nm} \text { ) }\end{array}$ & $\begin{array}{l}\text { Estudios o grado de deterioro } \\
\text { estructural de la matriz } \\
\text { (State or degree of structural } \\
\text { deterioration of matrix) }\end{array}$ \\
\hline $\begin{array}{c}\text { por encima } 65 \% \text { (above } 65 \% \text { ) } \\
\text { valor medio } 70 \% \\
\text { (average value } 70 \% \text { ) }\end{array}$ & $\begin{array}{l}\text { Hasta } 15 \mathrm{~nm} \\
\text { (up to } 15 \mathrm{~nm} \text { ) }\end{array}$ & $\begin{array}{l}\text { Estado original de la matriz } \\
\text { (Original state of matrix) }\end{array}$ \\
\hline $52-65 \%$ & $15-20 \mathrm{~nm}$ & $\begin{array}{c}\text { Grado I. Deterioro inicial hasta } \\
\text { el } 20 \% \\
\text { (Degree I. Initial deterioration } \\
\text { up to } 20 \% \text { ) }\end{array}$ \\
\hline $39-52 \%$ & $20-31 \mathrm{~nm}$ & $\begin{array}{c}\text { Grado II. Deterioro aproximado } \\
20-40 \% \\
\text { (Degree II. Deterioration } \\
\text { approx. } 20-40 \% \text { ) } \\
\end{array}$ \\
\hline $26-39 \%$ & $31-56 \mathrm{~nm}$ & $\begin{array}{c}\text { Grado III. Deterioro aproximado } \\
\text { 40-60\% } \\
\text { (Degree III. Deterioration } \\
\text { approx. } 40-60 \% \text { ) }\end{array}$ \\
\hline $13-26 \%$ & $56-130 \mathrm{~nm}$ & $\begin{array}{c}\text { Grado IV. Deterioro aproximado } \\
60-80 \% \\
\text { (Degree } \text { (V. Deterioration } \\
\text { approx. } 60-80 \% \text { ) }\end{array}$ \\
\hline $0-13 \%$ & $\begin{array}{l}\text { por encima de } 130 \mathrm{~nm} \\
\text { (above } 130 \mathrm{~nm} \text { ) }\end{array}$ & $\begin{array}{c}\text { Grado V. Deterioro por encima } \\
\text { del } 80 \% \text {. Colapso estructural } \\
\text { (Degree V. Deteriorarion above } \\
80 \% \text {. Structural failure) }\end{array}$ \\
\hline
\end{tabular}

unas resistencias próximas a cero. Debido a que algunas de estas muestras tenían más de 50 años, el efecto, si lo hubiere, del contenido de álcalis del hormigón inicial, no pudo ser evaluado.

Esas observaciones son concordantes con los aspectos ya conocidos de que la conversión se inicia en las zonas termodinámicamente menos estables, es decir; las de contacto entre los cristales de $\mathrm{CAH}_{10}$. Entonces, con una conversión relativamente baja (en las zonas de contacto) y estando todavía presentes muchos cristales de $\mathrm{CAH}_{10}$ no convertidos ( $\mathrm{y}$ de $\mathrm{C}_{2} \mathrm{AH}_{8}$ ), puede producirse un grado de daño estructural importante.

\section{Relación entre Conversión yResistencia Mecánica}

Como ya se ha dicho, es evidente que con una conversión incompleta pueden producirse unas pérdidas graves de resistencias. Por otra parte, como puede verse with corresponding strength close to zero. (Because some of these samples were more than 50 years old, the effect, if any, of the original alkali content of the concrete could not be evaluated).

These observations are in line with known facts, in that the conversion initiates at the thermodynamically least stable part of the structure, namely the contact zones between the individual crystallites of $C A H_{10}$.Thus, only a relatively minor conversion (at the contact zones), with large amounts of unconverted $C A H_{10}$ (and $C_{2} A H_{8}$ ) crystals still present, may lead to excessive degree of structural damage.

\section{Conversion versus Mechanical Strength}

It is clear, as stated, that dramatic strength losses can be observed at incomplete conversion. On the other hand, as illustrated in Figure 4, even at complete 
en la Figura 4, también una conversión total puede, a veces, darse en hormigones con resistencias aceptables, estando esto relacionado con la formación de estructuras secundarias de $\mathrm{C}_{3} \mathrm{AH}_{6}+\mathrm{AH}_{3}$. Esta resistencia residual es de importancia cuando se pretende emprender una reparación en una edificación antigua (p.ej. 10, 11).

Por consiguiente, la resistencia residual no está directamente relacionada con el grado de conversión y sí lo está con la estructura porosa. Ello se puede observar en la Figura 6 que muestra la relación entre la resistencia a compresión y la distribución relativa del tamaño de poros, en este caso representada por la media de los radios de los microporos. Esta relación se puede expresar de acuerdo a la siguiente función:

$$
\mathrm{R}=2.700 \cdot \mathrm{e}^{-3 \cdot 2 \log M}
$$

donde $\mathrm{R}$ es la resistencia a compresión en MPa y M es el radio medio de los microporos.

Esa relación es concordante con los datos experimentales, que muestran la importancia de la relación entre la resistencia y la microporosidad de los materiales cementantes. conversion one can sometimes obtain measurable strength, these being related to the formation of secondary structure of $C_{3} A H_{6}+A H_{3}$. This residual strength is of importance when a procedure for repair of an old structure is being considered (e.g., 10, 11).

Thus, the residual strength is not directly related to the degree of conversion but is directly influenced by the pore structure. This is illustrated in Figure 6, showing the relationship between the compressive strength and relative pore size distribution represented, in this case, by the median micropore radius. This functionality can be expressed as:

$$
R=2.700 \cdot e^{-3 \cdot 2 \log M}
$$

where $R$ is compressive strength in $M P a$ and $M$ is the median micropore radius.

This relationship is in line with the experimental experience showing the important relationship between strength and microporosity of cementitious materials.

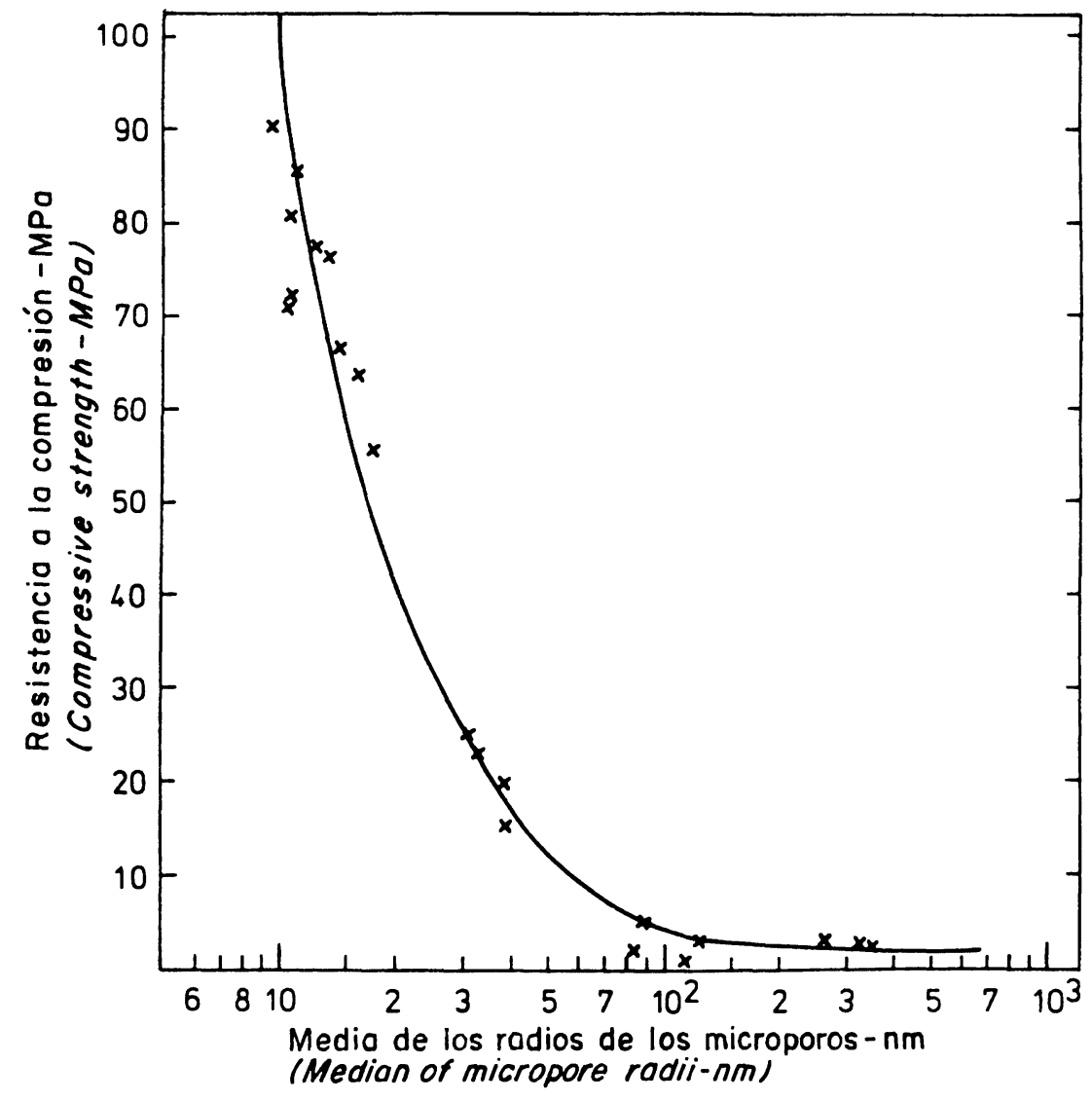

Fig. 6.- Resistencia a la compresión como una función de la media del radio de los microporos. Fig. 6.- Compressive strength as a function of median micropore radius. 


\section{RESUMEN DE CONCLUSIONES}

El trabajo aquí presentado y los datos extraídos de la bibliografía permiten presentar las siguientes conclusiones:

1.- Se confirman los efectos conocidos de las condiciones ambientales sobre la velocidad de conversión del cemento aluminoso. El grado de conversión y la consecuente pérdida de resistencia disminuye con la distancia a la superficie del hormigón afectado (por ej. profundidad del hormigón en los cimientos). Sin embargo, también se ha comprobado que en los hormigones más expuestos y más dañados el grado de conversión no ha sido total.

2.- La relación entre el grado de conversión y las pérdidas de resistencia es indirecta, a través de sus efectos sobre la estructura porosa. Así, el valor del grado de conversión en si mismo, no permite la estimación exacta de la resistencia residual de la estructura.

3.-Es posible que se produzca una degradación mecánica total de una pasta constituida originalmente por $\mathrm{CAH}_{10}+\mathrm{C}_{2} \mathrm{AH}_{6}$ y con grados de conversión relativamente bajos. Esto depende de la alteración en los contactos partícula-partícula en el sistema. Y, recíprocamente, también con una conversión total, es posible que se produzca un aumento de las resistencias debido a la formación de una nueva matriz de $\mathrm{C}_{3} \mathrm{AH}_{6}+$ $\mathrm{AH}_{3}$; sin embargo, tal resistencia rara vez alcanzaría los $15 \mathrm{MPa}$.

4.- La mejor medida del deterioro de la pasta es su estructura porosa. Una pasta no dañada se caracteriza típicamente por tener más del $70 \%$ de los poros con un radio inferior a $15-20 \mathrm{~nm}$ (se ha observado que el valor límite del volumen de poros total es del $65 \%$ ). El deterioro continuo de la pasta a causa de la conversión se caracteriza por un rápido descenso del volumen de poros con diámetros inferiores a 15-20 $\mathrm{nm}$ y por un aumento en los valores medios de los radios de los microporos, por encima de 15-20 nm. Ya que esos parámetros están relacionados con las resistencias residuales de los hormigones, es posible hacer una clasificación sencilla de los daños causados por la conversión.

5.- La determinación del radio medio de los poros, $\mathrm{M}$, en una matriz permite calcular aproximadamente la resistencia residual real, $R$, de la matriz:

$$
R=2.700 \cdot \mathrm{e}^{-3 \cdot 2 \log M}
$$

6.- El nuevo procedimiento propuesto para evaluar la resistencia residual de estructuras es una herramienta

\section{SUMMARY OF CONCLUSIONS}

The experimental and available literature data enable the following conclusions:

1.- The reported environmental effects on the rate of conversion of $C A C$ are confirmed. The degree of conversion and the subsequent strength loss diminish with the distance from the exposed concrete surface (e.g., depth of concrete within the foundation). However, even in the most exposed and damaged concrete, the degree of conversion was found to be incomplete.

2.- The relationship between the degree of conversion and the strength loss is indirect, through its effect on the pore structure. Thus, the degree of conversion by itself does not enable accurate estimation of the residual strength of the structure.

3. - A complete mechanical degradation of the original $\mathrm{CA} H_{10}+C_{2} A_{8}$ paste matrix is theoretically possible, although not probable, even at relatively low degree of conversion. This will depend on the damage to the particle-to-particle contacts available within system. Conversely, even at a complete conversion, some strength increase is possible due to the formation of a new paste matrix of $\mathrm{C}_{3} \mathrm{AH}+\mathrm{H}_{6}+\mathrm{AH}_{3}$; such strength seldom reaches $15 \mathrm{MPa}$, however.

4.- The best measure of the degradation of the paste matrix is its pore structure. An undamaged paste is typically characterized by $70+$ percent pores having a radius below 15-20 $\mathrm{nm}$ (65 percent of the total pore volume was found to be the limit). Continuous degradation of the paste due to conversion is characterized by rapid decrease of the volume of pores with diameters below 15-20 $\mathrm{nm}$ and an increase in the median pore radius to above 15-20 nm. Because these parameters are related to residual strength of the concrete structure, a simple categorization of the damage caused by the conversion is possible.

5.- Determination of the median radius of the pores, $M$, in a paste matrix enables approximate calculation of the actual residual strength, $R$, of the matrix structure:

$$
R \cdot 2.700 \cdot e^{-3 \cdot 2 \log M}
$$

6. - The above newprocedure for evaluation of the residual strengths of structures is a useful tool in evaluation of old, 
válida que puede ser aplicada en viejas estructuras de hormigón de cemento aluminoso CHCA aún existentes.

\section{AGRADECIMIENTOS}

Los autores agradecen a los Drs. C. Andrade, S. Goñi y J.F. Young por la revisión del manuscrito y los comentarios críticos. Asimismo expresan su gratitud a los Drs. F. Puertas y T. Vázquez por la traducción al español del manuscrito. still existing concrete structures built with CAC.

\section{ACKNOWLEDGMENTS}

Thanks are due to Drs. C. Andrade, S.Goni, and J.F.Young for reviewing the manuscript and for critical comments. We would also like to express our gratitude to Drs. F. Puertas and T. Vazquez for translating the manuscript into Spanish.

\section{BIBLIOGRAFÍA}

(1) J. JAMBOR: "Degradation of Concrete Made with Calcium Alumina Cement and its Control", Project Report, Inst. Constr. Archit., Slovak Academy Sci., January 1993.

(2) A. NEVILLE: "Proc.Inst.Civ.Eng., paper No. 6652, pp. 287-324.

(3) J. TEYCHENNE: Mag. Concr. Res. 27(1975), pp. 78-102.

(4) J. TALABER: Proc. 6th Int. Congr. Cem. Chem., Moscow 1976, III-4-20.

(5) V. LACH, M. MATOUSEK, AND J. JAMBOR: Stavivo 11(1985), pp. 465-477.

(6) D. SORRENTINO, F. SORRENTINO, AND M. GEORGE: "Mechanism of Hydration of Calcium Aluminate Cement", in Materials Science of Concrete IV (J. Skalny \& S. Mindess, Eds.), The American Ceramic Society, Westerville, OH, 1995, pp. 41-90.

(7) R. ALEGRE: Rev.des Mat. 628(1968), pp. 101-108.

(8) "High Alumina Cement Concrete in Buildings", Building Res. Establishment Rpt.CP 34/75 (1975); also: H. G. MIDGLEY AND A. MIDGLEY: Mag. Concr. Res. 27(1975), pp. 59-77.

(9) E.D. SHCHUKIN, E.A. AMELINA AND S.I. KONTOROVICH: "Formation of Contacts Between Particles and Development of Internal Stresses During Hydration Processes", in Materials Science of Concrete IU (J. Skalny, Ed.), The American Ceramic Society, Westerville, OH, 1992, pp. 1-35.

(10) (R.J. COLLINS AND W. GUTT: Mag. Concr. Res. 40(1988). pp. 195-208.

(11) (J. JAMBOR: Proc. 7th Int. Congr. Chem. Cem., Vol.IV, Paris 1980. pp. 487-492.

(12) (e.g., P.A. REHBINDER: Selected Works, Vol.2, Physico-Chemical Mechanics, Moscow, Nauka, 1979 (in Russian).

(13) (e.g., J.JAMBOR: Stavebnicky Casopis 12(1964), 6, pp. 321-337.

(14) H.F.W.TAYLOR; Cement Chemistry, Academic Press, 1990. 